\title{
Hepatoprotective effect of Ecballium Elaterium fruit juice against paracetamol induced hepatotoxicity in male albino rats
}

\author{
*Maraia Farag Elmhdwi, Saleh Mosbah Muftah, Salem Gaber El tumi, Fatma Al-zaroug Elslimani \\ Department of Chemistry (Biochemistry), Faculty of Science, Benghazi University, Libya
}

\begin{abstract}
This study was designed to investigate the antioxidant and hepatoprotective activity of Ecballium elaterium "Fruit juice" extract against paracetamol induced hepatotoxicity in male albino rats. The hepatotoxicity was induced by acetaminophen (PCM) at dose of $400 \mathrm{mg} / \mathrm{kg}$ in male albino rats. It was administered orally once a day, every $48 \mathrm{~h}$ at the same time for twenty two days. The biochemical liver functional tests ALT, AST, ALP, total bilirubin, total protein, antioxidant enzymes (GR, GPx, CAT, SOD), and histopathological changes were examined. Our results showed that Levels of liver enzymes ALT, AST, ALP, G-GT and total bilirubin and MDA level were significantly enhanced by administration of acetaminophen and level of total protein while antioxidant enzymes "GR, GPx, CAT, SOD" were decreased. However, the pretreatment with The E. elaterium "fruit juice" at $1 \mathrm{ml} / \mathrm{kg}$ orally revealed attenuation of serum ALT, AST, ALP. The histopathological studies also supported the protective properties of E. elaterium "fruit juice". The area of necrosis and degeneration of hepatocytes were observed in the toxic group. The prophylactic and curative groups showed a marked protective effect with decreased necrotic zones and hepatocellular degeneration. The present results clearly demonstrate the marked antihepatotoxic effects of E. elaterium "fruit juice" extract through its antioxidant activity on acetaminophen induced hepatotoxicity in rats.
\end{abstract}

Key Words: ALT, AST, ALP, MDA, SOD, antioxidant.

\section{INTRODUCTION}

Acetaminophen (APAP) (paracetamol) is a commonly used analgesic and antipyretic drug and is safe at therapeutic levels, but overdose can leads to potentially fatal hepatic necrosis in humans and experimental model animals (Proudfoot and Wright, 1970; Prescott, 1980; Kim et $a l, .2009)$. APAP overdose is one of the most common/frequent causes of liver failure in western world (Lee, 2004). At overdose APAP is metabolized in the liver by cytochrome P450 (CYP) into reactive metabolite $\mathrm{N}$ acetyl-p-benzoquinone imine (NAPQI) (Dahlin et al., 1984; James et al., 2003). NAPQI is known to deplete cellular glutathione (GSH), a natural antioxidant level and generate oxidative stress that turn into production of free radicals such as reactive oxygen (ROS) and reactive nitrogen species (NOS) (Mitchell et al., 1973). This results in imbalance of cellular antioxidant defense mechanism in liver hepatocyte cells and thus finally leads to hepatotoxicity (Reid et al., 2005). Due to known mode of its hepatotoxicity APAP is widely used as a model liver toxin for experimental validation of hepatoprotective drugs.

The production of various free radicals and successive oxidative stress leads to adverse effect on cellular level of an organ. Herbal antioxidants are widely used for the treatment and prevention of several diseases (Uttara et al., 2009). Current therapeutic research is directed towards finding naturally occurring antioxidants particularly of plant origin. Many plant species reported to possess potential biomolecules to become a source of hepatoprotective drugs and search is still going on to find the best one. Tangjang et al. (2011) has reported the uses of different plant species as hepatoprotective among the
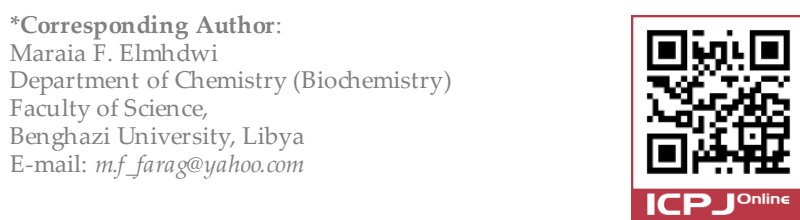

traditional medicine practitioners of Arunachal Pradesh, India.

There are several herbal formulation claimed have possessed beneficial activity in treating hepatic disorder. In one of our field survey we found that a widely grown plant Ecballium elaterium which has claimed to possess hepatoprotective property. The plant contains many biologically active compounds, includingcontains phenolic compounds, flavonoids "phytomelin" and triterpenoid (Chaudhari et al., 2009).

E. elaterium is a medicinal plant, whose fruit juice is used for the treatment of jaundice in folk medicine (Elayan et al., 1989). In Turkey, the fresh fruit juice of this plant is directly applied into the nostrils for the treatment of sinusitis as herbal folk remedy (Nidaljaradat et al., 2012). The juice of E. elaterium is fiber free but contains proteins, lipids, sugars, and minerals (Greige et al., 2007). The antioxidant properties of cucurbitacin B glucosides and cucurbitacin E glucosides (cucurbitacinglucoside combination, CGC) and their direct free radical scaven $\mathrm{g}$ ing properties were established (Andrea, 1997).

\section{MATERIALS AND METHODS}

\section{Chemicals}

Paracetamol was purchased from Sigma Aldrich, commercial kits to estimate antioxidant enzymes were from Biodignostic company, liver function tests were carried out in Benghazi medical center.

Preparation of Ecballium elaterium "fruit juice" The fruits of Ecballium elaterium were well crushed and then refined by filtration using Whatman filter paper No. 4. The refined crude juice was used as a plant material to study its effect in treatment of hepatotoxicity.

\section{Animals}

Twenty eight healthy adult male albino rats weighing between 110-120g were used for this study. The animals were kept in polypropylene cages and maintained at $24 \pm$ 
$3^{\circ} \mathrm{C}$ and a constant light-dark schedule (12 hours light and 12 hours dark cycle). The animals were allowed free access standard commercial rat chow (pellet form, in the sack, Benghazi Animal Feed Company, Benghazi, Libya) and water ad libitum.

\section{Experimental design}

The rats were adapted to laboratory condition for seven days before commencement of the experiment. Animals were divided into four groups of seven rats each and treated orally as below for 22 days (Roberts et al., 1991)-

Group 1: Rats were fed on the standard diet and served as negative control group.

Group 2: Rats were administered with paracetamol 400 $\mathrm{mg} / \mathrm{kg}$ body weight in distilled water orally every $48 \mathrm{~h}$ and served as positive control group.

Group 3: Rats were administered Ecballium elaterium "fruit juice" at a dose of $1 \mathrm{ml} / \mathrm{kg}$ body weight orally1 hour before oral administration of paracetamol.

Group 4: Rats were orally dosed daily with a single dose of $300 \mathrm{mg} / \mathrm{kg}$ body weight of vitamin C, 1 hour before oral administration of paracetamol.

\section{Sample collection and biochemical assays}

The blood samples obtained were collected into plain sample tubes and centrifuged at $1000 \mathrm{rev} / \mathrm{min}$ for 5 minutes to separate serum. Serum was carefully withdrawn and kept in eppendrof tubes for the determination of the biochemical parameters.

\section{Assessment of serum marker enzymes}

Serum level of ALT and AST, the potential biomarker of hepatic injury was estimated using a commercial kit (Medsource Ozone Biomedicals Pvt. Ltd) (Reitman and Frankel, 1957). Lactate Dehydrogenase (LDH) was determined using the method (Buchl et al., 1978). GGlutamyltransferase (GGT) by method (Shaw et al., 1983).Serum total protein (T. Protein was determined using the method) (Doumas et al 1981). Serum albumin (ALB) was analyzed by method described by Doumas and Biggs (1972). Serum total bilirubin (T. BIL) was determined using the method (Lott J A 1987). Alkaline phosphatase (ALP) was determined using the method (Tietz et al., 1983) were assayed using standard Diagnostic kits at Benghazi medical center.

\section{Assessment of antioxidant enzymes}

The activities of Glutathione reductase (GR) was determined using the method (Goldberg et al., 1983), Glutathione peroxidase (GPx) was determined using the method (Paglia and valentine, 1967). Catalase (CAT) was determined using the method (Aebi, 1984), Superoxide dismutase (SOD) was determined using the method (Nishikimi et al., 1972). Malondialdehyde (MDA) was determined using the method (Ohkawa et al., 1979). . Where assayed in research laboratory of biochemistry in Benghazi medical center.

\section{Histological assessment}

At the end of experiments, animals in all groups were scarified dislocation for histopathological studies, Liver samples were fixed in 10\% neutral buffered formalin overnight, washed well in running tap water, dehydrated, cleared in xylene and embedded in paraffin. Liver sections were cut into $5 \mu \mathrm{m}$ thickness, processed in alcohol grades and stained in haematoxylin and eosin (H\&E) (Luna, 1968) for histopathological examinations. Sections were photographed using canon digital image recorder.

\section{Statistical analysis}

Resulting data were represented as mean \pm SD. Statistical data was analyzed by T-test, between control vs. all treated groups. A probability level of less than $5 \%(p<0.05)$ was considered significant.

\section{RESULTS}

\section{Serum hepatic marker enzymes status}

Oral administration of paracetamol significantly increased the activities of ALT, AST, LDH, G-GT, ALP and T. Bili.by $332.68 \%, 166.80 \%, 204.29 \%, 258.60 \%, 70 \%$ and $340 \%$, respectively. Pretreatment of the rats with E. elaterium "fruit juice" at $1 \mathrm{ml} / \mathrm{kg}$ ameliorated these increases by $61.53 \%, 51.28 \%, 56.46 \%, 62.21 \%, 35.68 \%$ and $40.88 \%$,in ALT, AST, LDH, G-GT, ALP and T. Bili, respectively, when compared with positive group. The levels of total protein and albumin decreased significantly by $49.44 \%$, $66.38 \%$ respectively. But the level of total protein and albumin increased by $61.67 \%, 135.78 \%$ after treatment with E. elaterium "fruit juice" at $1 \mathrm{ml} / \mathrm{kg}$ when compared to the paracetamol treated group.

\section{Antioxidant enzymes status}

After the exposure of rats to paracetamol only a significant decrease in the activities of the antioxidant enzymes GR, GPx, CAT, and SOD, in comparison to the control group by $55.2 \%, 53.4 \%, 51.1 \%$, and $60.7 \%$ respectively, but the MDA level shows significant increase by $153.5 \%$. Pretreatment of the rats with E. elaterium "fruit juice" at $1 \mathrm{ml} / \mathrm{kg}$ increase the activity of these enzymes GR, GPx, CAT, and SOD by $89.5 \%, 72.2 \%, 77.3 \%$, and $111.5 \%$, respectively, and significant decrease in MDA by $44.3 \%$ when compared to the paracetamol treated group.

\section{Histopathology}

Aphotomicrographs of liver sections showed (figure 1-4) effect of various treatments: (1) Liver section of rat showing normal architecture of hepatocytes (control); (2) Liver section of rat treated with $400 \mathrm{mg} / \mathrm{kg}$ of paracetamol. (3) Liver section of rat treated with paracetamol and Ecballium elaterium "fruit juice" extract at $100 \mathrm{ml} / \mathrm{kg}$. (4) Liver section of rat treated with paracetamol and vitamin $\mathrm{C}$ at $300 \mathrm{mg} / \mathrm{kg}$

\section{DISCUSSION}

Hepatotoxicity is the potential complication of paracetamol, which is widely, used in general medicine and an assessment of its relative toxicity is important. The primary toxicity of paracetamol is the result of drug metabolism in liver. At therapeutic doses, paracetamol is metabolized via glucuronidation and sulfation reactions result in the water-soluble metabolites that are excreted via the kidney. The result of the metabolic conversion of paracetamol by the microsomal P-450 enzyme system is that, a highly reactive intermediate, namely, N-Acetyl-PBenzoquinone Imine (NAPQI) is produced. This metabolite is then reduced by Glutathione (GSH) (Jaeschkea et al., 2002; Gardner et al., 1998; Gardner et al., 2002).

GSH depletion makes the hepatocytes susceptible to the toxic effects of NAPQI. Its depletion allows NAPQI to binds irreversibly and covalently to cell macromolecules. Primary cellular targets have been postulated to be mitochondrial proteins, with resulting loss of energy production (Doshi et al., 2012).

This process disrupts homeostasis and initiates apoptosis "programmed cell death" leading to tissue necrosis and ultimately to organ dysfunction (Jaeschkea et al., 2002). Because liver damage arising from necrosis or 
Table 1: Effect of oral administration of paracetamol alone or with Ecballium elaterium "fruit juice" 1m1/kg or with vitamin C on serum liver functions.

\begin{tabular}{|c|c|c|c|c|}
\hline Parameter & Control & Positive & E. elaterium+ Paracetamol & Vitamin C + Paracetamol \\
\hline $\operatorname{ALT}(\mathrm{u} / \mathrm{l})$ & $43.45 \pm 3.72$ & $188.31 \pm 5.43^{a, * * *}$ & $72.43 \pm 4.66^{b, * * *}$ & $88.43 \pm 5.72$ b, $* * *$ \\
\hline $\operatorname{AST}(u / l)$ & $96.37 \pm 4.22$ & $257.12 \pm 8.57 a, * * *$ & $125.26 \pm 4.32^{b, * * *}$ & $138.6 \pm 5.78 \mathrm{~b}, * * * *$ \\
\hline $\mathrm{LDH}(\mathrm{u} / \mathrm{l})$ & $40.54 \pm 1.82$ & $123.36 \pm 4.52^{a, * * *}$ & $53.71 \pm 3.22 \mathrm{~b}, * * *$ & $48.87 \pm 5.01 \mathrm{~b}, * * *$ \\
\hline G-GT $(\mathrm{u} / \mathrm{l})$ & $3.72 \pm 1.61$ & $13.34 \pm 2.31^{a}, * * *$ & $5.04 \pm 0.57 \mathrm{~b}, * * *$ & $5.85 \pm 0.97 \mathrm{~b}, * * *$ \\
\hline $\operatorname{ALP}(\mathrm{u} / \mathrm{l})$ & $150 \pm 4.83$ & $255 \pm 2.53^{a, * * *}$ & $164 \pm 4.75^{b, * * *}$ & $171 \pm 3.93^{b, * * *}$ \\
\hline T. Bilirubin (mg/dl) & $0.45 \pm 0.14$ & $1.98 \pm 0.36^{\mathrm{a}, * * *}$ & $0.66 \pm 0.23 b, * * *$ & $0.71 \pm 0.35^{b, * * *}$ \\
\hline T. Protein (g/dl) & $8.98 \pm 0.80$ & $4.54 \pm 0.23 \mathrm{a}, * * *$ & $7.34 \pm 0.66^{b, * * *}$ & $6.84 \pm 0.54 b, * * *$ \\
\hline Albumin (g/dl) & $9.31 \pm 0.53^{+}$ & $3.13 \pm 0.28 \mathrm{a}, * * *$ & $7.38 \pm 0.11^{b}, * *$ & $6.93 \pm 0.47 b, * *$ \\
\hline
\end{tabular}

*Significant difference at $\mathrm{P}<0.05$; **highly sig. difference at $\mathrm{P}<0.01$; ${ }^{* * *}$ Very highly sig. difference at $\mathrm{P}<0.001$; $\downarrow$ Decrease; $\uparrow$ Increase; a $\mathrm{Compared}$ with control group; bcompared with paracetamol positive group.

Table 2: Effect of oral administration of paracetamol alone or with Ecballium elaterium "fruit juice" extract or with vitamin C on antioxidant enzymes activities.

\begin{tabular}{|c|c|c|c|c|}
\hline Parameter & Control & Positive & E. Elaterium+ Paracetamol & Vitamin C + Paracetamol \\
\hline GR & $26.14 \pm 0.05$ & $11.71 \pm 0.01^{\mathrm{a}^{* * * *}}$ & $22.19 \pm 0.02^{\mathrm{b}, * * *}$ & $20.37 \pm 0.02^{\mathrm{b}, * * *}$ \\
\hline GPx & $30.72 \pm 0.39$ & $14.31 \pm 0.03^{a^{* * * *}}$ & $24.65 \pm 1.21^{\mathrm{b}}$ & $21.23 \pm 2.14^{\mathrm{b}, *}$ \\
\hline CAT & $46.45 \pm 3.99$ & $22.71 \pm 3.32 \mathrm{a}^{{ }^{* *}}$ & $40.26 \pm 5.01^{\mathrm{b},{ }^{* *}}$ & $38.11 \pm 4.77 b^{, * *}$ \\
\hline SOD & $13.53 \pm 1.93$ & $5.31 \pm 1.57 \mathrm{a}^{, * * *}$ & $11.23 \pm 2.21^{\mathrm{b}, * *}$ & $9.81 \pm 2.31^{\mathrm{b}, * *}$ \\
\hline MDA & $19.35 \pm 3.66$ & $49.05 \pm 2.31^{\mathrm{a}^{* * * *}}$ & $27.30 \pm 3.09^{b, * *}$ & $22.11 \pm 4.05^{\mathrm{b}, * *}$ \\
\hline
\end{tabular}

*Significant difference at $\mathrm{P}<0.05 ;{ }^{*}$ highly sig. difference at $\mathrm{P}<0.01 ;{ }^{* *}$ Very highly sig. difference at $\mathrm{P}<0.001$; $\downarrow$ Decrease; $\uparrow$ Increase; acompared with control group; bcompared with paracetamol positive group.

membrane damage normally releases the enzymes into circulation; therefore, measurement of these enzymes in serum gives an indication of the health status of the liver. An increase in AST and ALT, a hepatospecific enzymes that is principally found in the cytoplasm in the rats following administration of a hepatotoxin is attributed to the increased release of enzymes from the damaged liver. It is known that an increase in the enzymatic activity of ALT and AST in the serum directly reflects a major permeability or cell rupture (Walubo et al., 2004; Kim et al., 2009; Jin et al., 2012).

Serum LDH, a cytoplasmic marker enzyme and GGT, a membrane bound enzyme are the well-known indicators of cell and tissue damage by toxic substances and their levels are also substantially increased in paracetamol-intoxicated rats. $\mathrm{LDH}$ is an intracellular enzyme, the increase of which in serum is an indicator of cell damage (Gujral et al., 2002). Serum ALP and bilirubin levels on other hand are related to the function of hepatic cell. (Kannan et al., 2013) The decline in total protein and albumin content can be deemed as a useful index of the severity of cellular dysfunction in chronic liver diseases (Fakurazi et al., 2012).

The decreased level of GSH has been associated with an enhanced level of lipid peroxidation in Paracetamol intoxicated groups of rats. Hepatic Oxidative Stress parameters where determined by elevated in the MAD level, while the activities of glutathione reductase (GSH), glutathione peroxidase (GPx), catalase (CAT) and superoxide dismutase (SOD) were decreased which consider as sensitive enzymatic index in liver injury caused by ROS and oxidative stress. All these were noted in paracetamol treated group. It is thought to be that fundamental antioxidant enzymes are closely related to the directly elimination of reactive oxygen species. Therefore the reduction in the activity of these enzymes may result in a number of deleterious effects due to the accumulation of superoxide radicals and hydrogen peroxide (Evan et al., 2009).
Administration of E. elaterium "fruit juice" $(1 \mathrm{ml} / \mathrm{kg})$ on paracetamol induced hepatotoxicity resulted in decreased levels of AST, ALT, ALP, LDH, G-GT, bilirubin and elevated total protein and albumin. This effect clearly indicated that "fruit juice" of E. elaterium may offer protection by stabilizing the cell membrane in hepatic damage induced by paracetamol. Furthermore it has been reported that E. elaterium "fruit juice" decreases the liver marker enzymes during carbon tetrachloride induced hepatotoxicity (Al-Howiriny, 2008; Jaeschkea et al., 2003).

Paracetamol is known to produce oxidative damage in the liver by enhancing peroxidation of membrane lipids, a deleterious process solely carried out by free radicals. Where hepatic peroxides are reported to be increased during oxidative stress (Jaeschkea et al. 2002).The free radicals attack the cell membrane, thus leading to destabilization and disintegration of the cell membrane as a result of lipid peroxidation (Jaeschkea et al., 2003). The depression in GSH contents along with GST activity makes the cells more susceptible to by toxic electrophilic compounds. In this study, the observed decrease in GPx an oxidative type of injury with acetaminophen-induced hepatotoxicity. The decrease in GPx is potentially ascribable to inactivation by the increase in reactive oxygen species (ROS) or lipid peroxides when oxidative damage is extreme (Lauterburg et al., 1983; Smilkstein et al., 1988).

Glutathione reductase (GR) is the enzyme responsible for the reduction of oxidized glutathione (GSSG) to GSH (Mitchell et al., 1973). The level of reduced glutathione and the activities of glutathione-dependent enzymes were reduced significantly in rats administered with acetaminophenin the present investigation. The depression in GR contents along with GPx activity makes the cells more susceptible to toxic compounds. Administration of PCM caused a reduction of GR and GPx levels in plasma.

Catalase (CAT) is one of the most important intracellular antioxidant enzymes in the detoxification of the oxidant hydrogen peroxide. Catalase, widely distributed 


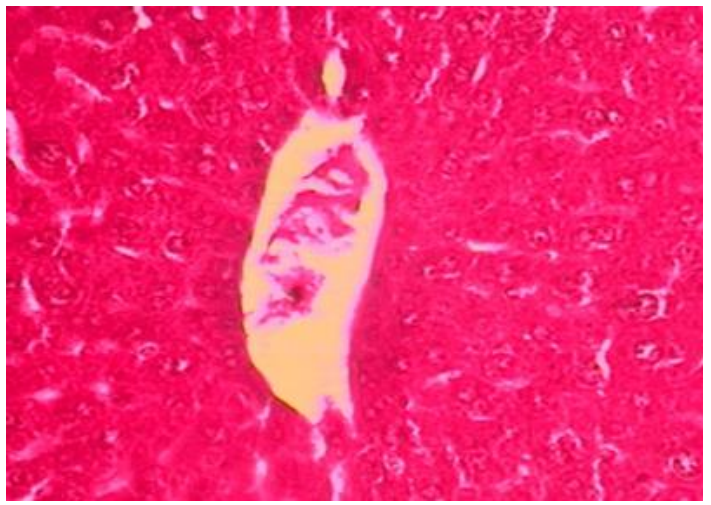

Figure 1: Liver cell of normal rat.

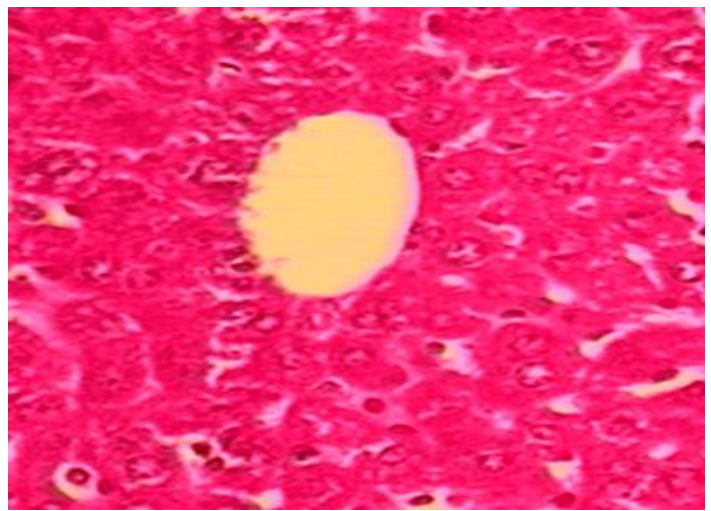

Figure 3: Liver cell treated by Ecballium elaterium" fruit juice" at $100 \mathrm{ml} / \mathrm{kg}$.

in all animal tissues, decomposes $\mathrm{H}_{2} \mathrm{O}_{2}$ by dismutating it to $\mathrm{H}_{2} \mathrm{O}$ and $\mathrm{O}_{2}$ (Bhakta et al., 1999) and protects tissue from reactive hydroxyl radicals. The activity of these enzymes was inhibited due to high level of toxic metabolites which produced by administration of PCM that significantly reduced CAT activity, indicating oxidative stress. A decrease in SOD production can be attributed to an enhanced superoxide generation. The activity of SOD enzyme in plasma was also determined. The group treated with PCM showed significantly lower plasma SOD activity than the control group.

In the present study, an elevation in the levels of MDA in the plasma of animals treated with acetaminophen was observed. The increase in MDA level suggests enhanced lipid peroxidation leading to tissue damage and failure of antioxidant defense mechanisms to prevent formation of excessive free radicals. Administration of PCM induced oxidative stress with a significant increase in the levels of plasma MDA.

According to our results about the antioxidant enzymes "GR, GPx, SOD and CAT" in addition to the lipid peroxidation indicator "MDA", we may suggest that the therapeutic potential of Ecballium elaterium "fruit juice" is dependent on an antioxidant mechanism. These results concluded that Ecballium elaterium "fruit juice" inhibition of PCM-induced tissue damage is due to presence of various antioxidant bioactive compounds which mediates its antioxidant effect by scavenging free reactive oxygen species (ROS).

In the present study, the hepatic histoarchitecture of the paracetamol-treated rats resulted severe necrotic changes, inflammatory cell infiltration, fatty degeneration

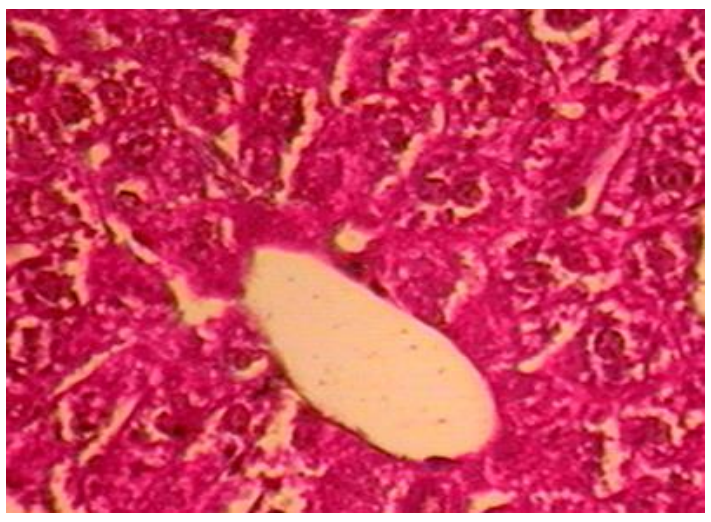

Figure 2: Liver cell of positive rat treated by $400 \mathrm{mg} / \mathrm{kg}$ of paracetamol.

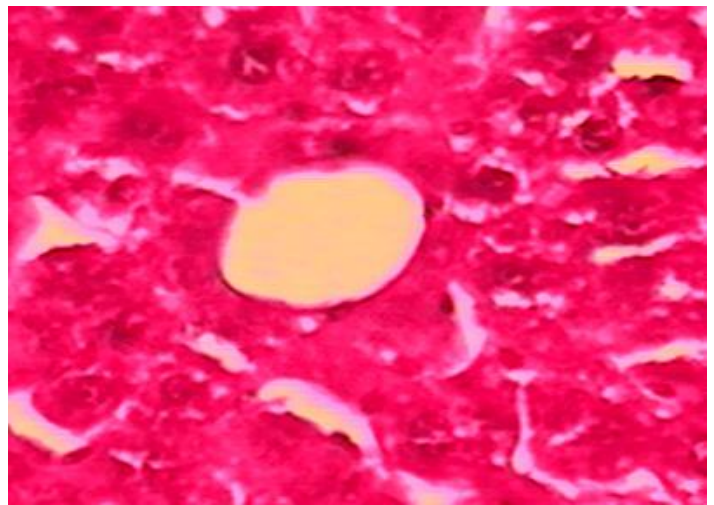

Figure 4: Liver cell treated by vitamin $C$ at $300 \mathrm{mg} / \mathrm{kg}$.

and vacuolization. It might be due to the formation of highly reactive radicals and subsequent lipid peroxidation induced by paracetamol. Administration of Ecballium elaterium "fruit juice" reduced the histological alterations provoked by paracetamol quite appreciable. It can be attributed to the antiradical/ antioxidant efficacy of Ecballium elaterium "fruit juice" which significantly reduced the oxidative stress leading to the reduction of histopathological alterations and restoration of normal physiological state of the liver.

\section{CONCLUSION}

In the present study, Ecballium elaterium "fruit juice" possessed strong hepatoprotective in a rat model of paracetamol-induced hepatotoxicity. The hepatoprotective activity of Ecballium elaterium "fruit juice" may be due to its free radical-scavenging and antioxidant activity, resulting from the presence of some phenolic compounds in the fruit juice of plant. In general, to use this plant as safe prophylactic agent, more studies should be carried out to know all the active components and their mechanism of actions weather synergistic or antagonist using different doses from this plant and another types of experimental animals for a long period in order to judgment if this plant could be used as safe agents or not in human therapy. 


\section{REFERENCES}

Aebi, H. (1984) Catalase in vitro, Methods in Enzymology, 105, 121-126.

Al-Howiriny, A.T., (2008). Protective effect of 'purslane' on rat liver injury induced by carbon tetrachloride .Saudi Pharmaceut. J., 16: 239-244.

Andrea, Beth, Paterson. (1997). Mechanisms of acetaminophen-induced hepatotoxicity: effects of mitochondrial glutathione, protein thiols and oxidatne phosphorylation; Queen's University, Kingston, Ontario, Canada.; 1-106.

Bergmeyer HU, Horder M, Rej R. (1986).Approved recommendation on IFCC methods for the measurement of catalytic concentration of enzymes. Part 2. IFCC method for Aspartate aminotransferase. J. Clin. Chem. Clin. Biodhem. 24: 497-510.

Bhakta, T., PulokK.M., Kakali M., Banerjee S., Subhash C.M., Tapan KM., Pal M., Saha B., P. (1999). Evaluation of hepatoprotective activity of Cassia fistula leaf extract. J Ethnopharmacol., 66, 227.

Buchl SN, Jackson KY, Graffunder B (1978).optimal Reaction condition for Assaying Human lactate dehydrogenase pyruvate-to-lactate at 20, 30 and $27^{\circ} \mathrm{C}$. Clin. Chem. 24:261-266.

Chaudhari N. B., Chittam K. P., Patil V. R., (2009) Hepatoprotective Activity of Cassia fistula Seeds against Paracetamol-Induced Hepatic Injury in rats, Arch Pharm Sci\& Res July. 1 (2)

Dahlin DC, Miwa GT, Lu AY, Nelson SD. (1984) N-acetyl pbenzoquinimine: a cytochrome $\mathrm{P} 450$ mediated oxidation product of acetaminophen. Proceedings of the National Academy of Sciences, USA 81: 327- 1331. PMCID: PMC344826

Doshi K, Ilanchezhian R, Acharya R, Patel BR, Ravishankar B. (2012) Anti-inflammatory activity of root bark and stem bark of Shyonaka. Journal of Ayurveda \& Integrative Medicine 3(4): 194-197. [DOI]

Doumas BT, Biggs HG (1972). Determination of serum albumin. Standard methods in clinical dhemistry. 7:175-188.

Doumas BT, et al (1981). A candidate reference method for determination of total protein in serum: 1 . Development and validation. Clin. Chem. 27:1642-1650.

Elayan, H., H., Garaibeh, M., N., Zmeili, S., M., Salhab, S., A. (1989). Effects of Ecballium elaterium juice on serum bilirubin concentration in male rats, Int. J. Crude Drug Res. 27, 227-234.

Evan prince Sabina, Jaisy Samuel, Segu Rajappa Ramya et al,. (2009). Hepatoprotective and antioxidant potential of spirulinafusiformis on acetaminophen-induced hepatotoxicity in mice., International journal of integrative biology, 6, 1,1.

FakuraziS, Sharifudin, SA, Arulselvan, P. (2012) Moringa oleifera hydroethanolic extracts effectively alleviate acetaminophen-induced hepatotoxicity in experimental rats through their antioxidant nature. Molecules 17: 8334-8350. [DOI]

Gardner CR, Heck DE, Yang CS, Thomas PE, Zhang XJ, De George GL, Laskin JD, Laskin DL. (1998) Role of nitric oxide in acetaminophen induced hepatotoxicity in the rat. Hepatology 27: 748-754 [DOI]

Gardner CR, Laskin JD, Dambach DM, Sacco M, Durham SK, Bruno MK, Cohen SD, Gordon MK, Gerecke DR, Zhou P, et al. (2002) Reduced hepatotoxicity of acetaminophen in mice lacking inducible nitric oxide synthase: Potential role of tumor necrosis factor-alpha and interleukin10. Toxicology and Applied Pharmacology 184: 27-36. [DOI]

Goldberg D.M. et al. (1983) in methods of Enzymatic Analysis (Bergmeyen, H.V. Ed.) 3rd end. Vol 3, Pp 258-265, Verlog Chemie, Deerfield Beach, $\mathrm{Fi}$.

Greige-Gerges, H, Khalil, RA, Mansour, EA, Magdalou, J., Chahine R, Ouaini N. (2007).Cucurbitacins from Ecballium elaterium juice increase the binding of bilirubin and ibuprofen to albumin in human plasma. ChemBiol Interact. 169, 1, 53-62.

Gujral JS, Knight TR, Farhood A, Bajt ML, Jaeschke H. (2002) Mode of cell death after acetaminophen overdose in mice: apoptosis or oncotic necrosis? Toxicological Sciences 67:322-328 [DOI]

Jaeschkea H, Gores GJ, Cederbaum AI, Hinson JA, Pessayre D, Lemasters JJ. (2002) Mechanisms of hepatotoxicity. Toxicological Sciences 65: 166176. [DOI]

Jaeschkea H, Knighta TR, Bajta, ML. (2003) The role of oxidant stress and reactive nitrogen species in acetaminophen hepatotoxicity. Toxicology Letters 144(3): 279-288. [DOI]

James LP, Mayeux PR, Hinson JA. (2003) Acetaminophen-induced hepatotoxicity. Drug Metabolism and Disposition 31: 1499-1506. [DOI]
Jin SM, Kil HR, Park K Noh CI. (2012). Gene expression in rat hearts following oral administration of a single hepatotoxic dose of acetaminophen. Yonsei Medical Journal 53(1): 172-180. [DOI]

Kannan N, Sakthivel KM, Guruvayoorappan, C. (2013). Protective Effect of Acacia nilotica (L.) against Acetaminophen-Induced Hepatocellular Damage in Wistar Rats. Advances in Pharmacological Sciences 2013: 19. [DOI]

Kim SJ, Lee MY, Kwon DY, Kim SY, Kim YC. (2009). Alteration in Metabolism and Toxicity of Acetaminophen upon repeated administration in rats. Journal of Pharmacological Sciences 111: 175-181. [DOI]

Lauterburg BH, Corcoran BG, Mitchell, JR. (1983) Mechanism of Action of $\mathrm{N}$-Acetylcysteine in the Protection against the Hepatotoxicity of Acetaminophen in Rats In Vivo. Journal of Clinical Investigation 71(4): 980-991. [DOI]

Lee WM. (2004) Acetaminophen and the U.S. Acute Liver Failure Study Group: Lowering the risks of hepatic failure. Hepatology 40: 6-9. [DOI

Lott J A (1987). New concept in serum bilirubin measurement. Laboratory mangment.

Luna LG (1968). In Manual of histological staining - Methods of armed forces, Institute of Pathology: 3rd ed. London, UK: Blakiston Division, McGraw-Hill.

Mitchell JR, Jollow DJ, Potter WZ, Gillette JR, Brodie BB. (1973) Acetaminophen-induced hepatic necrosis. IV. Protective role of glutathione. Journal of Pharmacology and Experimental Therapeutics 187: 211-217. PMID: 4746329

Nidaljaradat, Shehdeh, Jodehb, Tamararinnob, Maherkharoofc, Abdelnaserzaida, Mohamedhannon. (2012). Determination the presence of phytomelin in Ecballium elaterium to approve its folk uses. International Journal of Pharmacy and Pharmaceutical Sciences. 4(2): 233-237.

Nishikimi M, Roa N A \& Yogi K (1972) Biochem Biophys Res Common 46, 849-854

Ohkawa, H., ohishi W, and Yagi K (1979). Anal. Biochem, 95, 351.

Paglia D. E. and. valentine W. N (1967) J. Lab Clin. Med. 70: 158-169.

Prescott LF. (1980) Hepatotoxicity of mild analgesics. British Journal of Clinical Pharmacology 10: 373-379. PMID: 7002191

Proudfoot AT, Wright N. (1970) Acute Paracetamol poisoning. British Medical Journal 3: 557- 558. PMCID: PMC1701561

Reid AB, Kurten RC, McCullough SS, Brock RW, Hinson JA. (2005) Mechanisms of Acetaminophen Induced Hepatotoxicity: Role of Oxidative Stress and Mitochondrial Permeability Transition in Freshly Isolated Mouse Hepatocytes. Journal of Pharmacology and Experimental Therapeutics 312: 509-516. [DOI]

Reitman S, Frankel S. (1957) A colorimetric method for the determination of serum glutamic oxalacetic and glutamic pyruvic transaminases. American Journal of Clinical Pathology 28: 56-63. PMCID:13458125.

Roberts, D., W., Bucci, T., J., Benson R.W., Warbritton A.R., McRae T.A., PumfordN.R. and Hinson J.A. (1991). Immunohistochemical localization and quantification of the 3-(cystein-S-yl)acetaminophen-protein adduct in acetaminophen hepatotoxicity. American Journal of Pathology, 138, 359-371

Shaw LM, Stromme JH, London JL, Theodorsen L (1983). IFCC methods for the measurement of catalytic concentration of enzymes. Part 4. IFCC method for gamma-glutamyltransferase. J. Clin. Chem. Clin. Biochem. 21: 633-646.

Smilkstein MJ, Knapp GL, Kulig KW, Rumack BH. (1988) Efficacy of Oral $\mathrm{N}$-Acetylcysteine in the treatment of Acetaminophen overdose. The New England Journal of Medicine 319: 1557-1562. [DOI]

Tangjang S, Namsa ND, Arana C, Litin A. (2011) An ethnobotanical survey of medicinal plants in the Eastern Himalayan zone of Arunachal Pradesh, India. Journal of Ethnophamacology 134: 18-25. [DOI]

Tietz NW, Rinker AD, Shaw LM (1983). IFCC methods for the measurement of catalytic concen tration of enzymes. Part 5. IFCC method for alkaline phosphatase. J Clin. Chem., Clin. Biochem. 21: 731-748.

Uttara B, Singh AV, Zamboni P, Mahajan RT. (2009) Oxidative stress and neurodegenerative diseases: a review of upstream and downstream antioxidant therapeutic options. Current Neuropharmacology 7: 65-74 [DOI]

Walubo A, Barr S, Abraham AM, Coetsee C. (2004) The role of cytochromeP450 inhibitors in the prevention of hepatotoxicity after paracetamol overdose in rats. Human \& Experimental Toxicology 23(1): 49-54. [DOI] 